\title{
Evolution in the Hypervariable Region of Hepatitis C Virus in Infants after Vertical Transmission
}

\author{
JUN MURAKAMI, MANABU OKAMOTO, HIRONORI MIYATA, IKUO NAGATA, \\ KAZUO SHIRAKI, AND SHIGEO HINO \\ Departments of Pediatrics [J.M., M.O., I.N., K.S.] and Virology [S.H.], Faculty of Medicine, Tottori \\ University, Yonago, Japan
}

\begin{abstract}
To elucidate the clonal evolution of hepatitis $\mathrm{C}$ virus (HCV) during mother-to-infant transmission, we prospectively analyzed $\mathrm{HCV}$ clones of the hypervariable region in four HCV RNApositive infants and compared them with those of the mother. Cord blood samples from three of the four infants were positive for the HCV RNA $\left(\leq 10^{3}\right.$ copies $\left./ \mathrm{mL}\right)$, and all of the four infants had the HCV RNA titer of $>10^{6}$ copies $/ \mathrm{mL}$ within 2 mo after birth. The hypervariable region clones detected in the infants were closely related to those in the respective mothers. The results suggest the perinatal transmission of HCV. The hypervariable region clones transmitted to infants were not a single selected clone or minor clones in the mother. None of the clones specific to the low-density fraction in the mother was transmitted to the infants. Moreover, the proportion of HCV in the lowdensity fraction was minimal in the first few months of life, but
\end{abstract}

\section{ABSTRACT}

increased several months after birth in association with the elevation of alanine aminotransferase. These results suggest that the increase of $\mathrm{HCV}$ in the low-density fraction reflect the evolution of immune response in infants. We also demonstrated that the emergence of quasispecies in infants precedes the infantile antibody response. (Pediatr Res 48: 450-456, 2000)

$\quad$ Abbreviations
HCV, hepatitis C virus
HVR, hypervariable region
RT-PCR, nested PCR coupled with reverse transcription
NTR, 5'-nontranslating region
LDF, low-density fraction
HDF, high-density fraction
ALT, alanine aminotransferase

Chronic HCV infection is associated with liver cirrhosis and hepatocellular carcinoma $(1,2)$. Approximately half of patients with chronic HCV infection have a history of blood transfusion (3). The incidence of mother-to-infant transmission of $\mathrm{HCV}$ is up to $10 \%$ of infants born to HCV-positive mothers (4-8). $\mathrm{HCV}$ infection after mother-to-infant transmission can be persistent $(4,5,9)$, and the clinical course varies from asymptomatic, transient hepatitis to chronic hepatitis $(10,11)$. Because $\mathrm{HCV}$ infection associated with blood transfusion has essentially been eliminated in countries employing blood donor screening (12), the proportion of mother-to-infant transmission to overall new $\mathrm{HCV}$ infections should become greatly increased.

The HVR, the N-terminus region of glycoprotein 2 (E2) of $\mathrm{HCV}$, is one of the major targets of neutralizing antibodies (4, $13,14)$ and cellular immunity (15). Vertical transmission of $\mathrm{HCV}$ is confirmed by a close relationship between the HVR sequences of HCV in the mother and infant pair $(5,16,17)$.

Received November 5, 1999; accepted May 23, 2000.

Correspondence and reprint requests: Dr. Shigeo Hino, Department of Virology, Faculty of Medicine, Tottori University, 86 Nishi, Yonago 683-8503, Japan.
The major survival strategy used by HCV against humoral and cellular immunosurveillance systems by the host seems to be the continuous mutation of its HVR in an immunocompetent host to form subpopulations or quasispecies $(14,15,18,19)$. Spontaneous remission from chronic hepatitis $\mathrm{C}$ may occur in children with low HCV RNA load (20).

$\mathrm{HCV}$ particles in the serum can be divided into two populations based on their densities. Inoculation into chimpanzees revealed that $\mathrm{HCV}$ in the $\mathrm{HDF}$ was less infective than that in the LDF (21). Immunoprecipitation demonstrated that the HDF HCV consisted of immune-complexed particles and nucleocapsids $(22,23)$. In a tissue culture system, the immune complexed population was less infective (24). Patients with active hepatitis tend to have abundant $\operatorname{HDF} \operatorname{HCV}(22,23,25,26)$. If this observation could be extended for the mother-to-infant transmission of $\mathrm{HCV}$, the $\mathrm{HCV}$ clone(s) responsible for infection in the infant would be preferentially present in the LDF of the maternal serum at delivery. To elucidate the clonal evolution of $\mathrm{HCV}$ in the mother-to-infant transmission, we analyzed the HCV HVR in the LDF and HDF of four HCV-infected infants infected via the RNA-positive mother. 


\section{METHODS}

Patients. We screened 18,380 pregnant women for antiHCV antibody from April 1992 to December 1997 using a second-generation assay based on passive hemagglutination (HCV PHA, Dainabot, Tokyo, Japan). Seropositive mothers were further screened for HCV RNA by nested RT-PCR targeting on the NTR. We prospectively followed 59 infants born to the HCV RNA-positive mothers. Sera of these infants were tested for anti-HCV antibody, HCV RNA, and liver function every 3 mo during the first year and every $6 \mathrm{mo}$ thereafter. The RT-PCR for HCV RNA yielded positive signals in six infants on at least two occasions. The other infants were consistently negative. All six positive infants born to four HCV-positive mothers were positive for HCV RNA at the age of 1 mo. A pair of siblings born 2 y apart was excluded from this study because their $\mathrm{HCV}$ was genotype $2 \mathrm{~b}$ reactive to the RT-PCR directed for NTR but inapplicable to that directed for HVR. The other four cases involved genotype $1 \mathrm{~b} \mathrm{HCV}$. Cases 2 and 3 were born to the same mother. Each case was delivered vaginally and free from other viral infections, including hepatitis B virus and HIV. Cases 1-3 were bottle-fed, and case 4 was both breast- and bottle-fed. The maternal grandmother of case 1 was positive for $\mathrm{HCV}$. Enrolled mothers consented to the study before the screening and after the delivery. This study has been approved by the ethics committee of the Faculty of Medicine, Tottori University.

Anti-HCV antibody titer. We used a third-generation kit for titration of anti-HCV antibody based on an enzyme immunoassay (anti-HCV 3rd, Sympep HCV-EIA II, Kyokuto Med. Corp., Tokyo).

Detection and titration of HCV RNA. For detection of the HCV RNA, a nested RT-PCR targeting on NTR of the HCV genome (26) was applied with the minimum detection level of 200 HCV RNA copies/mL of serum. The HCV RNA load was titrated by a sandwich hybridization assay kit using the bDNA amplifier molecules according to the method recommended by the supplier (Quantiplex Version 1.0, Chiron Corp., Emeryville, CA, U.S.A.). The HCV genotype was determined by a nested RT-PCR kit (Sumai Test, Tokusyu-MenekiKenkyusyo, Tokyo, Japan) using genotype-specific primers designed from the core region.

Differential flotation centrifugation. The density population of HCV in serum was analyzed by the method of Hijikata et al. (22) with minor modifications. A $50-\mu \mathrm{L}$ aliquot of the serum was layered on top of an $8-\mathrm{mL} \mathrm{NaCl}$ solution with a density of $1.063 \mathrm{~g} / \mathrm{cm}^{3}$, and centrifuged in a Beckman $70.1 \mathrm{Ti}$ rotor at $145,000 \times \mathrm{g}$ for $22 \mathrm{~h}$ at $14^{\circ} \mathrm{C}$. RNA was extracted from $50 \mu \mathrm{L}$ each of the top and bottom 1-mL fraction. Approximately $90 \%$ of the HCV RNA that was layered on was recovered in the top and bottom 1-mL fractions (26). After serial 10-fold dilutions, the end point dilution was determined by RT-PCR using quintuplicate tubes, and the HCV RNA titer was computed by the Behrens-Kärber method (27). To estimate the relative amount of virions in the LDF, the ratio of the HCV RNA in the top fraction to that in the combined top and bottom fractions was computed.
Amino acid sequence analysis of HVR. For sequencing the HVR, a nested RT-PCR directed for the E2/NS1 region (28) was applied with minor modifications (29). RNA was extracted as described above, and cDNA was transcribed using primer A1 $\left(5^{\prime}-G^{1692}\right.$ CT CCG GGC ACC CGG ACG AGT TGA $\mathrm{A}^{1668}-3^{\prime}$, based on HCV-J (30). DNA was amplified for 50 cycles in the first PCR using a thermal cycler (PC-700, ASTEK, Fukuoka, Japan). Each cycle consisted of the following: $94^{\circ} \mathrm{C}$ for $1 \mathrm{~min}\left(3 \mathrm{~min}\right.$ for the first cycle), $61^{\circ} \mathrm{C}$ for $1 \mathrm{~min}$, and $72^{\circ} \mathrm{C}$ for $1 \mathrm{~min}(7 \mathrm{~min}$ for the last cycle). The reaction mixture in a volume of $50 \mu \mathrm{L}$ contained $10 \mathrm{mM}$ Tris- $\mathrm{HCl}, \mathrm{pH}$ 9.0, $50 \mathrm{mM} \mathrm{KCl}, 1.5 \mathrm{mM} \mathrm{MgCl}, 0.25 \mathrm{mM}$ each dNTP, 25 pmol each of the outer primer pair (Primer S1 $\left(5^{\prime}-G^{1261} C C\right.$ ATT TAT CAG GTC ACC GCC ATG GC ${ }^{1285}-3^{\prime}$ '] and A1), $1.25 \mathrm{U}$ of Taq polymerase (Pharmacia Biotech, Uppsala, Sweden), $0.005 \mathrm{U}$ of Deep Vent DNA polymerase (New England Biolabs, Beverly, MA, U.S.A.), 5\% DMSO, and 2\% glycerol. The Deep Vent DNA polymerase containing a $3^{\prime}-5^{\prime}$ proofreading exonuclease activity was used to enhance the fidelity of the PCR. A 5- $\mu \mathrm{L}$ aliquot was used for the second PCR with the inner primer pair of A2 $\left(5^{\prime}-\mathrm{G}^{1634} \mathrm{GT}\right.$ GTG GAG GGA GTC ATT GCA GTT $\left.{ }^{1611}-3^{\prime}\right)$ and S2 $\left(5^{\prime}-\mathrm{G}^{1284} \mathrm{CT}\right.$ TGG GAT ATG ATG ATG AAC TGG $\left.\mathrm{TC}^{1309}-3^{\prime}\right)$ for 35 cycles; each cycle consisted of $94^{\circ} \mathrm{C}$ for $1 \mathrm{~min}$ ( $3 \mathrm{~min}$ for the first cycle), $57^{\circ} \mathrm{C}$ for $1 \mathrm{~min}$, and $72^{\circ} \mathrm{C}$ for $1 \mathrm{~min}(7 \mathrm{~min}$ for the last cycle). The amplified DNA fragment with the expected size was cloned into the EcoRV site of p-BlueScript. Fifteen clones from each fraction were sequenced in both directions by the dideoxynucleotide chain termination method using a DNA sequencer (ALFred, Pharmacia Biotech). Amino acid sequence of HVR was deduced from the DNA sequence. Clones were classified in the same group if there were less than three amino acid changes.

Statistical analysis. Dichotomous data were analyzed by Fisher's exact test.

\section{RESULTS}

Clinical background of the infants infected with HCV from their mothers. The peak ALT levels recorded in the four infants were $199,43,84$, and $125 \mathrm{IU} / \mathrm{L}$, respectively, which were noted between 3 and 8 mo of the age (Fig. $1, A-D$ ). In case 1, the fluctuating ALT level was persistently elevated over $100 \mathrm{IU} / \mathrm{L}$ during the ages of 6-10 and 11-12 mo. In cases 2 and 3, the ALT level was under $100 \mathrm{IU} / \mathrm{L}$ until the age of 12 mo. In case 4, the ALT level remained over $100 \mathrm{IU} / \mathrm{L}$ between 3 and 5 mo of age. Antibody titers of each infant declined in the first several months and increased again starting from 3 to 6 mo, suggesting loss and dilution of maternal antibodies followed by de novo production of infantile antibody. ALT values peaked after the lowest antibody titer in each infant (Fig. 1, $A-D$ ).

Cord blood samples of cases 1-3 were positive for $\mathrm{HCV}$ RNA by RT-PCR. However, the HCV RNA titer $\left(\leq 10^{3}\right.$ copies/ $\mathrm{mL}$ ) was too low to be detected by the bDNA assay. The HCV RNA titer was already high at the age of 1 mo in each case $\left(>10^{6}\right.$ copies $\left./ \mathrm{mL}\right)$, and remained at that level for at least 5 mo. In cases $1-3, \mathrm{HCV}$ RNA never disappeared throughout the 

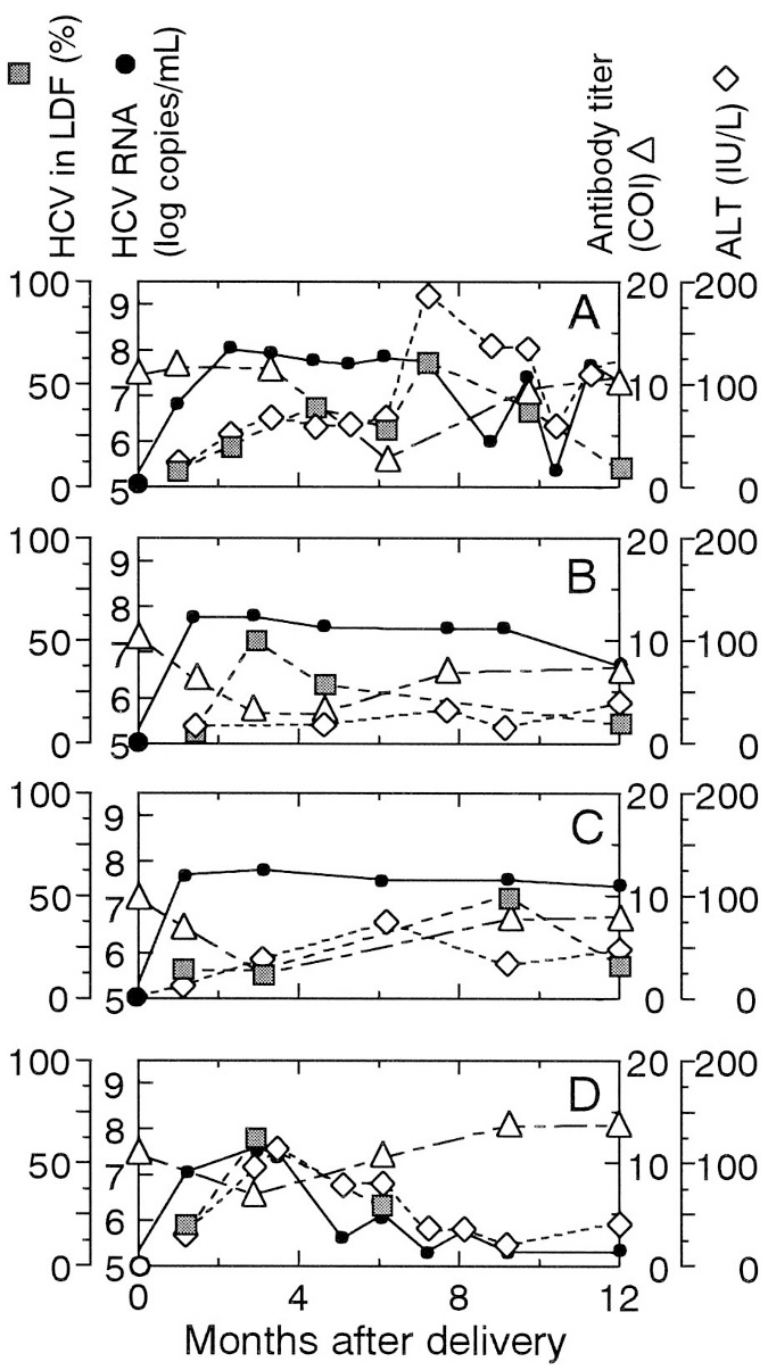

Figure 1. Clinical profiles of cases 1-4 $(A-D)$. Proportion of HCV in LDF ( $\%$, hatched rectangle), HCV RNA titer determined by the bDNA assay (copies/mL in logarithm, small closed circles), anti-HCV antibody titer determined by the third-generation assay (COI: cut-off index, triangle), and serum ALT level (100 IU/L, diamond). HCV RNA in cord blood was positive in cases 1-3 (large closed circle) and negative in case 4 (large open circle) by RT-PCR (minimum detection level; 200 copies $/ \mathrm{mL}$ ).

observation period. In case 4 , the titer became undetectable at the age of 9 mo by the bDNA assay and at the age of 16 mo by RT-PCR.
The ratio of $\mathrm{HCV}$ in the LDF was less than $20 \%$ in each case at $1-2$ mo after birth. The ratio of the LDF virions increased approximately 2 mo after the increase of HCV RNA in cases 1 , 2 , and 4 , but several months after in case 3 . The increase of this ratio was followed by the elevation of ALT level at 1-4 mo and $6-7$ mo in case 1 , and at $1-3$ mo in case 4 . In cases 2 and 3 , the increase in ratio was not accompanied by significant elevation of the ALT. The results suggest that the increase in ratio is not accompanied by the increase of HCV RNA titer in the serum.

HCV-HVR Evolution in case 1. The HVR clones detected in the case 1 mother and infant pair could be classified into seven groups (Gr): Gr101-Gr107 (Table 1). In the mother at delivery, two Gr101 and nine Gr105 clones appeared in the LDF, and nine Gr101 and four Gr105 clones in the HDF ( $p=$ $0.019)$. In the infant at the age of $2 \mathrm{mo}$, all of the 15 clones in the HDF were clone A of Gr101; the HCV RNA was undetectable in the LDF by RT-PCR for HVR. At the age of 4 mo, there were 4 Gr101 and 11 Gr105 clones in the LDF and 11 Gr101 and 4 Gr105 clones in the HDF ( $p=0.027)$.

The profile changed at the age of 9 mo: six Gr101 and nine Gr105 clones in the LDF, and seven Gr101 and eight Gr105 clones in the HDF. It changed further at the age of $12 \mathrm{mo}$. There were only two Gr101 clones in the HDF, and all others in the LDF and HDF were in the Gr106 and Gr107, which were closely related with the Gr105. However, none of the Gr105 clones in the infant (clones I-L, O, and P) were identical to the Gr105 clones in the mother (clone E). Clones of the Gr102Gr104 of the mother with the frequency of 2/15 each never appeared in the infant. By the age of $4 \mathrm{mo}$, new clones that were never detected in the mother emerged, occurring $2 \mathrm{mo}$ before the lowest antibody titer.

HCV-HVR evolution in cases 2 and 3. The HVR clones of the mother at 6 mo before and at 1 mo after the delivery of case 2 could be classified into six groups, Gr201-Gr206 (Table 2). In the mother, Gr201 and Gr203 were not present at 6 mo before delivery and first appeared in the HDF at 1 mo after delivery. Because Gr205 and Gr206 were not detected in case 2 throughout the study, they may not have been transmitted at all. Eighteen months after the birth of case 2, the same mother gave birth to case 3, during which clones of groups Gr201Gr203 persisted and of groups Gr304-Gr308 emerged (Table 3). The latter groups were similar to each other. Although

Table 1. Evolution of HVR clones in case 1 by relative frequencies in the LDF and HDF

\begin{tabular}{|c|c|c|c|c|c|c|c|c|c|c|c|c|}
\hline \multirow{3}{*}{$\begin{array}{l}\text { Clone } \\
\text { group* }\end{array}$} & \multirow[b]{3}{*}{ AA sequence } & \multirow{2}{*}{\multicolumn{2}{|c|}{$\begin{array}{c}\text { Mother at } \\
\text { delivery }\end{array}$}} & \multicolumn{8}{|c|}{ Case 1 at the age of } & \multirow[b]{3}{*}{ Name of clones } \\
\hline & & & & \multicolumn{2}{|c|}{2 months } & \multicolumn{2}{|c|}{4 months } & \multicolumn{2}{|c|}{9 months } & \multicolumn{2}{|c|}{12 months } & \\
\hline & & LDF & HDF & LDF & $\mathrm{HDF}$ & LDF & $\mathrm{HDF}$ & LDF & $\mathrm{HDF}$ & LDF & HDF & \\
\hline Gr102 & QS........ASG.AG...P.... & & 2 & & & & & & & & & $\mathrm{H}$ \\
\hline Gr103 & ЕАН.Т..К............ & 2 & & & & & & & & & & G \\
\hline Gr104 & $\ldots \ldots \ldots$ A...R.VS..SP .... & 2 & & & & & & & & & & F \\
\hline Gr107 & $\ldots \ldots \ldots \ldots$. $\ldots$ VG. SS $_{2} \ldots$ & & & & & & & & & 1 & & $\mathrm{X}$ \\
\hline Total & & 15 & 15 & 0 & 15 & 15 & 15 & 15 & 15 & 15 & 15 & \\
\hline
\end{tabular}

* Clones were classified in the same group if there were fewer than 3 amino acid (AA) changes. 
Table 2. Evolution of HVR clones in case 2 by relative frequencies in the $L D F$ and HDF

\begin{tabular}{|c|c|c|c|c|c|c|c|c|c|c|}
\hline \multirow{3}{*}{$\begin{array}{l}\text { Clone } \\
\text { group* }\end{array}$} & \multirow[b]{3}{*}{ AA sequence } & \multicolumn{4}{|c|}{ Mother at $\dagger$} & \multicolumn{4}{|c|}{ Case 2 at the age of } & \multirow[b]{3}{*}{ Name of clones } \\
\hline & & \multicolumn{2}{|c|}{-6 months } & \multicolumn{2}{|c|}{+1 month } & \multicolumn{2}{|c|}{1 month } & \multicolumn{2}{|c|}{3 months } & \\
\hline & & LDF & HDF & LDF & HDF & LDF & $\mathrm{HDF}$ & LDF & $\mathrm{HDF}$ & \\
\hline Gr202 & $\ldots \ldots \ldots \ldots$ S.L.N. . & & 4 & 3 & 2 & 4 & 10 & & 1 & C-E,S,T \\
\hline Gr203 & $\ldots \ldots \ldots$ SSL.T. . & & & & 3 & & & & & $\mathrm{~J}, \mathrm{~K}$ \\
\hline Gr204 & 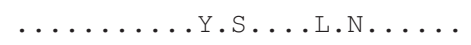 & & 4 & 12 & 9 & & & & & $\mathrm{~B}, \mathrm{H}$ \\
\hline Total & & 0 & 15 & 15 & 15 & 15 & 15 & 15 & 15 & \\
\hline
\end{tabular}

* See footnote to Table 1 for clone groups. Clone groups in italic indicate common to case 3 .

$\uparrow$ Mother before $(-)$ and after $(+)$ the delivery.

Table 3. Evolution of HVR clones in case 3 by relative frequencies in the $L D F$ and HDF

\begin{tabular}{|c|c|c|c|c|c|c|c|c|}
\hline \multirow{3}{*}{$\begin{array}{l}\text { Clone } \\
\text { group* }\end{array}$} & \multirow[b]{3}{*}{ AA sequence } & \multirow{2}{*}{\multicolumn{2}{|c|}{$\begin{array}{c}\text { Mother at } \\
\text { delivery }\end{array}$}} & \multicolumn{4}{|c|}{ Case 3 at the age of } & \multirow[b]{3}{*}{ Name of clones } \\
\hline & & & & \multicolumn{2}{|c|}{1 month } & \multicolumn{2}{|c|}{9 months } & \\
\hline & & LDF & HDF & LDF & HDF & LDF & HDF & \\
\hline Gr202 & $\ldots \ldots \ldots \ldots$ m.L.N. K. & 3 & 2 & & 6 & 6 & 6 & $\mathrm{C}, \mathrm{D}, \mathrm{p}-\mathrm{t}$ \\
\hline Gr203 & $\ldots \ldots \ldots \ldots \ldots$ SSL.T. . . & & 4 & & & & & $\mathrm{~J}, \mathrm{n}, \mathrm{o}$ \\
\hline Gr304 & 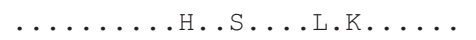 & 1 & 1 & & & & & $\mathrm{e}, \mathrm{k}$ \\
\hline Gr307 & 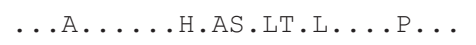 & & 1 & & & & & $\mathrm{~m}$ \\
\hline Gr308 & $\ldots \ldots \ldots$ HAASGLT. L... . . & 6 & 7 & 6 & 6 & 9 & 8 & $\mathrm{~g}, \mathrm{~h}, \mathrm{w}-\mathrm{z}$ \\
\hline Total & & 15 & 15 & 15 & 15 & 15 & 15 & \\
\hline
\end{tabular}

* See footnote to Table 1 for clone groups. Clone groups in italic indicate common to case 2.

$\dagger$ Name of the clones in upper case indicates common clone to case 2, and in lower case distinct in case 3 .

Gr204 was the major component of the mother at 1 mo after the delivery of case 2, only two clones were detected in Gr304 closely related to Gr204 in the mother at delivery of case 3. Although the Gr203 persisted in the mother at the delivery of case 3, the group was not transferred to case 3.

All of the clones isolated from case 2 at the ages of 1-3 mo were Gr201 and Gr202 (Table 2). At the age of $1 \mathrm{mo}$, the Gr201 was more abundant in the LDF, and the Gr202 in the HDF $(p=0.066)$. By the age of $3 \mathrm{mo}$, the Gr201 clones became dominant consisting of $15(100 \%)$ and $14(93 \%)$ clones in the LDF and HDF, respectively. Thus, in spite of the absence of the Gr201 in the mother before delivery, it probably existed in the mother as a minor component.

Case 3 at the age of 1 mo had four groups: Gr201, Gr202, Gr306, and Gr308, all detected in both LDF and HDF of the mother at time of delivery (Table 3 ). At the same age, all these groups were also detected in both LDF and HDF of the mother at delivery. However, the population in each group has been changed. For example, whereas the groups Gr304, Gr305, and Gr307 in the mother disappeared from the infant, the Gr306 in the infant had not been observed in the mother except in one clone. At the age of 9 mo, only a single clone in the Gr201, clone j, was still present. Although $40 \%$ of the clones belonged to the Gr202 in both LDF and HDF (clones D, r-t), the majority of clones were newly emerged derivatives in the Gr308 (clones h, w-z).

HCV-HVR evolution in case 4. Among five groups detected in case 4 at the age of $1 \mathrm{mo}, \mathrm{Gr} 401$ (clones A and B) and Gr402 (clones $\mathrm{G}$ and $\mathrm{H}$ ) were both in the LDF and HDF (Table 4). The Gr410 clones were not detectable in the mother, which were fairly distant from other clones in the HDF of case 4 at the age of $1 \mathrm{mo}$. At the age of $3 \mathrm{mo}$, only two groups, Gr401 and Gr402, were detectable in the LDF and HDF, and Gr401 formed the majority. The Gr401 clones were not detectable in the mother at 3 mo after delivery, and only one Gr403 clone related to Gr402 was detected in the mother.

The profile markedly changed at the age of 6 mo. Whereas Gr404 became dominant in the LDF, Gr410 became dominant in the HDF. Both groups were detected at 1 mo but not at 3 mo. The former was detectable in the mother but not the latter. Interestingly, Gr404 and Gr409 clones present at the age of 1 mo, once disappeared at the age of $3 \mathrm{mo}$, reappeared at the age of 6 mo. The Gr401 and Gr402 clones formed the majority at the age of 3 mo after delivery but completely disappeared at the age of 6 mo. A variety of clone groups was observed in the mother at 3 mo after delivery that were never seen in the child: Gr405-Gr408, Gr411, and Gr412.

\section{DISCUSSION}

The mother-to-infant transmission of $\mathrm{HCV}$ is one of the several established pathways for HCV transmission, affecting up to $10 \%$ of infants born to mothers chronically infected with HCV but not with HIV (4-8). However, its mechanism remains to be elucidated. Both in utero (16) and perinatal (5) transmissions have been proposed. 
Table 4. Evolution of HVR clones in case 4 by relative frequencies in the $L D F$ and HDF

\begin{tabular}{|c|c|c|c|c|c|c|c|c|c|c|}
\hline \multirow{3}{*}{$\begin{array}{l}\text { Clone } \\
\text { group* }\end{array}$} & \multirow[b]{3}{*}{ AA sequence } & \multirow{2}{*}{\multicolumn{2}{|c|}{$\begin{array}{c}\text { Mother at } \dagger+3 \\
\text { months }\end{array}$}} & \multicolumn{6}{|c|}{ Case 4 at the age of } & \multirow{3}{*}{$\begin{array}{c}\text { Name of } \\
\text { clones }\end{array}$} \\
\hline & & & & \multicolumn{2}{|c|}{1 month } & \multicolumn{2}{|c|}{3 months } & \multicolumn{2}{|c|}{6 months } & \\
\hline & & LDF & HDF & LDF & $\mathrm{HDF}$ & LDF & $\mathrm{HDF}$ & LDF & $\mathrm{HDF}$ & \\
\hline Gr402 & S.Y....A.N.K.A...TL.SN.R & & & 7 & 5 & 5 & 2 & & & F-I \\
\hline Gr403 & S.Y....A.N.K.A...L.S. . & & 1 & & & & & & & $\mathrm{~J}$ \\
\hline Gr404 & S.Y....TAYN.R.L....L.S. . & 2 & 3 & 2 & & & & 11 & 3 & $\mathrm{~K}-\mathrm{Q}$ \\
\hline Gr407 & 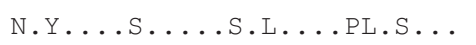 & 2 & & & & & & & & $\mathrm{~V}, \mathrm{~W}$ \\
\hline Gr408 & D.Y...S...S.LA..AP.QS . & 2 & 4 & & & & & & & $\mathrm{X}, \mathrm{Y}$ \\
\hline Gr409 & 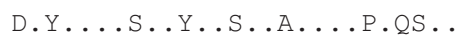 & 1 & & 2 & 1 & & & 4 & 1 & $\mathrm{a}-\mathrm{c}$ \\
\hline Gr410 & E.H.T..S.AR .SSLARFLAP ..S . & & & & 4 & & & & 11 & $\mathrm{Z}$ \\
\hline Gr411 & .Н...А..... . . F.SR.N & & 5 & & & & & & & $d-f$ \\
\hline Gr412 & 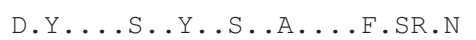 & & 1 & & & & & & & $\mathrm{~g}$ \\
\hline
\end{tabular}

* See footnote to Table 1 for clone groups.

$\dagger$ Mother after $(+)$ the delivery.

Previous studies suggested that HCV RNA is undetectable in the cord blood of infected infants $(5,31)$. In this study, whereas three out of four cord blood samples of infected infants possessed the HCV RNA at the titer of $\leq 10^{3}$ copies $/ \mathrm{mL}$, only one (4\%) did out of 28 uninfected infants born to HCV RNA positive mothers (data not shown). Positive signals in the cord blood sample only detectable by nested PCR are not informative for in utero transmission of either HTLV-1 (32) or HIV (33). All four cases in this study had extremely high levels of viremia $\left(>10^{7}\right.$ copies $\left./ \mathrm{mL}\right)$ at the age of 1-2 mo, although a previous report found the peak titer at 3-14 mo in 3 of 4 infants (5). Because the rapid boost of HCV RNA within a few months after delivery is hard to explain by the in utero transmission, the results strongly suggest the perinatal transmission.

We analyzed $15 \mathrm{HCV}$ HVR clones each in mothers and infants at various points. Although we did not confirm the reproducibility of the test by repetition, we considered them acceptable because the similarity of clones at different time points of each patient and the detection of the identical clones in the sibling of cases 2 and 3 served as the internal control.

The close similarity of HVR clones in each mother-infant pair molecularly confirmed the mother-to-infant transmission of HCV in our cases. Weiner et al. (16) found that $10 \mathrm{HVR}$ clones obtained from a baby at $24 \mathrm{~h}$ after birth were all the same but unique from 10 clones obtained from the mother suggesting selective transfer of HCV to the infant. Ni et al. (34) also reported the homogeneous population of $\mathrm{HCV}$ in infants at the age of $3 \mathrm{mo}$. In case of the mother-to-infant transmission of $\mathrm{HIV}$, the transmission of both selective clones $(35,36)$ and multiple maternal clones (37-39) has been reported. However, several factors, such as intrauterine and cell-associated transmissions, may play additional roles in the mother-to-infant transmission of HIV.

In our cases, although the HVR population in case 1 at the age of 2 mo was homogeneous, those of cases 2-4 were heterogeneous. Moreover, clones that emerged beyond the first few months were in the same group as those in the mother. Because the titer of $\mathrm{HCV}$ in the mother was $>10^{6}$ copies $/ \mathrm{mL}$ and that in the cord blood was $<10^{3}$ copies $/ \mathrm{mL}$ in each case, the HCV dose to the infant at the time of delivery was calculated as $\sim 10^{4}$ copies. Considering the presence of noninfectious particles and efficiency of transmission, the number of $\mathrm{HCV}$ particles precipitated in each infection would be minimal. Because we picked only 15 clones at each stage, minor clones would be undetectable and some clones might emerge later than the observation period. These results suggest that the number of HCV clones transmitted in each case is not necessarily limited to a few clones.

Kudo et al. (17) suggested that the clones transmitted to infants are minor clones in the mother, because the clones of infants were related, but not identical, to those of the mothers. Clone A appeared in $7 / 30$ of the mother at delivery of case 1 , clone $\mathrm{C}$ in $4 / 15$ of the mother at 6 mo before delivery of case 2 , and clone $g$ in $12 / 30$ of the mother at delivery of case 3 . Our results suggest that the clones transmitted to the infants are not always the minor clones in the mother at delivery. This is not surprising as the mother-to-infant transmission is expected to depend on the mother's quasispecies complexity and status of antibody repertory at the time of infection.

Previous studies suggested that HCV virions in the LDF are more infective than those in the $\operatorname{HDF}(21,22)$ and are responsible for the mother-to-infant transmission (17). However, in case 1 at 2 mo after delivery, all 15 A clones in the HDF were identical to $7 \mathrm{~A}$ clones in the HDF of the mother. In case 2 at the age of 1 mo, Gr201 and Gr202 were observed. The Gr201 was absent in the mother at 6 mo before delivery, but the Gr202 was in the HDF. In case 3 at the age of $1 \mathrm{mo}$, Gr202 was only in the HDF, and Gr201, Gr306, and Gr308 were both in the LDF and HDF. Of these, Gr201 and Gr306 were detected only in the LDF of the mother. In case 4 at the age of $1 \mathrm{mo}$, Gr401 and Gr402 were both in the LDF and HDF. These clones were absent in the mother at 3 mo after delivery, except for a single related clone in the Gr403. Gr410, which was fairly distant from others in the HDF at the age of $1 \mathrm{mo}$, was not detectable in the mother. The results suggest that clones transmitted to newborn babies do not always belong to the LDF of the mother. Because not all antibodies are capable of neutralization, we consider that at least some HDF HCV are still 
infective. The selective replication of $\mathrm{HCV}$ in the first few months of life probably reflect the maternal antibody and the evolution of infantile immune response.

The proportion of HCV in the LDF increased a few months after the rise of HCV RNA in serum, and its peak coincided with the nadir of antibody titer in the infant. Our results suggest that the increase of $\mathrm{HCV}$ in the LDF reflects the loss of maternal antibody and the evolution of antibody generation in infants. Ni et al. reported the slower nucleotide substitution rate in infants (34), and Kudo et al. suggested the role of infantile immunity for the selection of new quasispecies (17). Clones I-N of case 1 (in Gr101 and Gr105) emerged at the age of 4 mo. Clones L-P (in Gr201 and Gr202) and $\mathrm{u}-\mathrm{v}$ (in Gr306) of cases 2 and 3, respectively, emerged at the age of 1 mo. Furthermore, the majority of the LDF clones were not the newly emerged clones but preexisting clones. Because these preceded the lowest antibody titer in each infant, our results suggest that emergence of new quasispecies in infants reflect the evolution of cell-mediated immune response (15).

Although ALT level never exceeded $100 \mathrm{IU} / \mathrm{L}$ in cases 2 and 3 , it surpassed that level in cases 1 and 4 . Case 4 showed a single rise point of the ALT level above $100 \mathrm{IU} / \mathrm{L}$ at the age of $3 \mathrm{mo}$, and case 1 showed multiple bouts of ALT elevation. All cases had more than $10^{7}$ copies/mL of HCV RNA at least in the first $3 \mathrm{mo}$, and only case 4 became free of $\mathrm{HCV}$ within the observation period. Fujisawa et al. (20) suggested that children with a low titer of HCV RNA tend to recover spontaneously. However, the HCV titers at the age of 2-4 mo in our data did not support the concept. Yamaguchi et al. (40) reported a patient who eventually became HCV RNA-negative after frequent substitutions in the HVR. Quasispecies emerged in all four cases. Although the mother of case 4 had the most diverse quasispecies among them, the clonal diversity of case 4 was not remarkably different from other cases. To provide more convincing evidence, a larger number of cases should be studied.

In summary, our study suggests that the major route of mother-to-infant transmission of $\mathrm{HCV}$ is established during the perinatal period, and that the $\mathrm{HCV}$ responsible for the transmission is not restricted to a virus in the LDF or a single minor clone. We also demonstrated that the emergence of quasispecies in infants precedes the infantile antibody response.

Acknowledgments. The authors thank Koichi Irie, MD, Akio Nagata, MD, Naoki Terakawa, MD, Tadataka Hoshika, MD and Ryu Matsuda, MD, for collecting samples and clinical data, and Toshio Kamahora, PhD, and Sachiko Ishikura for technical advice and assistance.

\section{REFERENCES}

1. Kiyosawa K, Sodeyama T, Tanaka E, Gibo Y, Yoshizawa K, Nakano Y, Furuta S, Akahane Y, Nishioka K, Purcell RH, Alter HJ 1990 Interrelationship of blood transfusion, non-A, non-B hepatitis and hepatocellular carcinoma: analysis by detection of antibody to hepatitis $\mathrm{C}$ virus. Hepatology 12:671-675

2. Takano S, Yokosuka O, Imazeki F, Tagawa M, Omata M 1995 Incidence of hepatocellular carcinoma in chronic hepatitis B and C: a prospective study of 251 patients. Hepatology 21:650-655

3. Alter MJ, Margolis HS, Krawczynski K, Judson FN, Mares A, Alexander WJ, Hu PY, Miller JK, Gerber MA, Sampliner RE, Meeks EL, Beach MJ 1992 The natural history of community-acquired hepatitis $\mathrm{C}$ in the United States. The Sentinel Counties Chronic Non-A, Non-B Hepatitis Study Team. N Engl J Med 327:1899-1905
4. Nagata I, Iizuka T, Harada Y, Okada T, Matsuda R, Tanaka Y, Tanimoto K, Shiraki K 1994 Prospective study of mother-to-infant transmission of hepatitis $\mathrm{C}$ virus. In: Nishioka K, Suzuki H, Mishiro S, Oda T, eds. Viral Hepatitis and Liver Disease. Springer-Verlag, Tokyo, pp 468-470

5. Ohto H, Terazawa S, Sasaki N, Sasaki N, Hino K, Ishiwata C, Kako M, Ujiie N, Endo C, Matsui A, Okamoto H, Mishiro S, The Vertical Transmission of Hepatitis C Virus Collaborative Study Group 1994 Transmission of hepatitis C virus from mothers to infants. N Engl J Med 330:744-750

6. Chang MH 1996 Mother-to-infant transmission of hepatitis C virus. Clin Invest Med 19:368-372

7. Spencer JD, Latt N, Beeby PJ, Collins E, Saunders JB, McCaughan GW, Cossart YE 1997 Transmission of hepatitis C virus to infants of human immunodeficiency virus-negative intravenous drug-using mothers: rate of infection and assessment of risk factors for transmission. J Viral Hepat 4:395-409

8. Thomas DL 1999 Mother-infant hepatitis C transmission: second generation research. Hepatology 29:992-993

9. Nagata I, Shiraki K, Tanimoto K, Harada Y, Tanaka Y, Okada T 1992 Mother-toinfant transmission of hepatitis C virus. J Pediatr 120:432-434

10. Zanetti AR, Tanzi E, Paccagnini S, Principi N, Pizzocolo G, Caccamo ML, D'Amico E, Cambie G, Vecchi L 1995 Mother-to-infant transmission of hepatitis C virus. Lombardy Study Group on Vertical HCV Transmission Lancet 345:289-291

11. Palomba E, Manzini P, Fiammengo P, Maderni P, Saracco G, Tovo PA 1996 Natural history of perinatal hepatitis C virus infection. Clin Infect Dis 23:47-50

12. Japanese Red Cross Non-A Non-B Hepatitis Research Group 1991 Effect of screening hepatitis $\mathrm{C}$ virus antibody and hepatitis $\mathrm{B}$ virus core antibody on incidence of post transfusion hepatitis. Lancet 338:1040-1041

13. Kato N, Sekiya H, Ootsuyama Y, Nakazawa T, Hijikata M, Ohkoshi S, Shimotohno K 1993 Humoral immuno response to hypervariable region 1 of the putative envelope glycoprotein (gp70) of hepatitis C virus. J Virol 67:3923-3930

14. Farci P, Shimoda A, Wong D, Cabezon T, De Gioannis D, Strazzera A, Shimizu Y, Shapiro M, Alter HJ, Purcell RH 1996 Prevention of hepatitis C virus infection in chimpanzees by hyperimmune serum against the hypervariable region 1 of the envelope 2 protein. Proc Natl Acad Sci U S A 93:15394-15399

15. Weiner A, Erickson AL, Kansopon J, Crawford K, Muchmore E, Hughes AL, Houghton M, Walker CM 1995 Persistent hepatitis C virus infection in a chimpanzee is associated with emergence of a cytotoxic T lymphocyte escape variant. Proc Natl Acad Sci U S A 92:2755-2759

16. Weiner AJ, Thaler MM, Crawford K, Ching K, Kansopon J, Chien DY, Hall JE, Hu F, Houghton M 1993 A unique, predominant hepatitis C virus variant found in an infant born to a mother with multiple variants. J Virol 67:4365-4368

17. Kudo T, Yanase Y, Ohshiro M, Yamamoto M, Morita M, Shibata M, Morishima T 1997 Analysis of mother-to-infant transmission of hepatitis C virus: quasispecies nature and buoyant densities of maternal virus populations. J Med Virol 51:225-230

18. Okamoto H, Kojima M, Okada S, Yoshizawa H, Iizuka H, Tanaka T, Muchmore EE, Peterson DA, Ito Y, Mishiro S 1992 Genetic drift of hepatitis C virus during an 8.2-year infection in a chimpanzee: variability and stability. Virology 190:894-899

19. Higashi Y, Kakumu S, Yoshioka K, Wakita T, Mizokami M, Ohba K, Ito Y, Ishikawa T, Takayanagi M, Nagai Y 1993 Dynamics of genome change in the E2/NS1 region of hepatitis C virus in vivo. Virology 197:659-668

20. Fujisawa T, Komatsu H, Inui A, Miyagawa Y, Onoue M, Sekine I, Yokota S, Hanada R, Yamamoto K, Inui M 1997 Spontaneous remission of chronic hepatitis C in children. Eur J Pediatr 156:773-776

21. Bradley D, McCaustland K, Krawczynski K, Spelbring J, Humphrey C, Cook EH 1991 Hepatitis C virus: buoyant density of the factor VIII-derived isolate in sucrose. J Med Virol 34:206-208

22. Hijikata M, Shimizu YK, Kato H, Iwamoto A, Shih JW, Alter HJ, Purcell RH, Yoshikura H 1993 Equilibrium centrifugation studies of hepatitis C virus: evidence for circulating immune complexes. J Virol 67:1953-1958

23. Kanto T, Hayashi N, Takehara T, Hagiwara H, Mita E, Naito M, Kasahara A, Fusamoto H, Kamada T 1994 Buoyant density of hepatitis C virus recovered from infected hosts: two different features in sucrose equilibrium density-gradient centrifugation related to degree of liver inflammation. Hepatology 19:296-302

24. Shimizu YK, Hijikata M, Iwamoto A, Alter HJ, Purcell RH, Yoshikura H 1994 Neutralizing antibodies against hepatitis $\mathrm{C}$ virus and the emergence of neutralization escape mutant viruses. J Virol 68:1494-1500

25. Kanto T, Hayashi N, Takehara T, Hagiwara H, Mita E, Naito M, Kasahara A, Fusamoto H, Kamada T 1995 Density analysis of hepatitis C virus particle population in the circulation of infected hosts: implications for virus neutralization or persistence. J Hepatol 22:440-448

26. Okamoto M, Nagata I, Murakami J, Hino S, Shiraki K 1999 Shift in the buoyant density of HCV particles in infants infected by mother-to-infant transmission. Pediatr Int 41:369-373

27. Kärber G 1931 Beitrag zur kollektiven Behandlug pharmakologischer Reihenversuche. Arch Exp Pathol Pharmacol 162:480-483

28. Enomoto N, Kurosaki M, Tanaka Y, Marumo F, Sato C 1994 Fluctuation of hepatitis $\mathrm{C}$ virus quasispecies in persistent infection and interferon treatment revealed by single-strand conformation polymorphism analysis. J Gen Virol 75:1361-1369

29. Cheng S, Chang SY, Gravitt P, Respess R 1994 Long PCR. Nature 369:684-685

30. Kato N, Hijikata M, Ootsuyama Y, Nakagawa M, Ohkoshi S, Sugimura T, Shimotohno K 1990 Molecular cloning of the hepatitis C virus genome from Japanese patients with non-A, non-B hepatitis. Proc Natl Acad Sci U S A 87:9524-9528

31. Moriya T, Sasaki F, Mizui M, Ohno N, Mohri H, Mishiro S, Yoshizawa H 1995 Transmission of hepatitis $\mathrm{C}$ virus from mothers to infants: its frequency and risk factors revisited. Biomed Pharmacother 49:59-64 
32. Katamine S, Moriuchi R, Yamamoto T, Terada K, Eguchi K, Tsuji Y, Yamabe T, Miyamoto T, Hino S 1994 HTLV-I proviral DNA in umbilical cord blood of babies born to carrier mothers. Lancet 343:1326-1327

33. Biggar RJ, Mtimavalye L, Justesen A, Broadhead R, Miley W, Waters D, Goedert JJ, Chiphangwi JD, Taha TE, Miotti PG 1997 Does umbilical cord blood polymerase chain reaction positivity indicate in utero (pre-labor) HIV infection? AIDS 11:1375-1382

34. Ni YH, Chang MH, Chen PJ, Lin HH, Hsu HY 1997 Evolution of hepatitis C virus quasispecies in mothers and infants infected through mother-to-infant transmission. J Hepatol 26:967-974

35. Wolinsky SM, Wike CM, Korber BTM, Hutto C, Parks WP, Rosenblum LL, Kustman KJ, Furtado MR, Munoz JL 1992 Selective transmission of human immunodeficiency virus type-1 variants from mothers to infants. Science 255:1134-1137

36. Mulder-Kampinga GA, Kuiken C, Dekker J, Scherpbier HJ, Boer K, Goudsmit J 1993 Genomic human immunodeficiency virus type 1 RNA variation in mother and child following intra-uterine virus transmission. J Gen Virol 74:1747-1756
37. Briant L, Wade CM, Puel J, Brown AJ, Guyader M 1995 Analysis of envelope sequence variants suggests multiple mechanisms of mother-to-child transmission of human immunodeficiency virus type 1. J Virol 69:3778-3788

38. Pasquier C, Cayrou C, Blancher A, Tourne-Petheil C, Berrebi A, Tricoire J, Puel J, Izopet J 1998 Molecular evidence for mother-to-child transmission of multiple variants by analysis of RNA and DNA sequences of human immunodeficiency virus type 1. J Virol 72:8493-8501

39. Wade CM, Lobidel D, Brown AJ 1998 Analysis of human immunodeficiency virus type 1 env and gag sequence variants derived from a mother and two vertically infected children provides evidence for the transmission of multiple sequence variants. J Gen Virol 79:1055-1068

40. Yamaguchi K, Tanaka E, Higashi K, Kiyosawa K, Matsumoto A, Furuta S, Hasegawa A, Tanaka S, Kohara M 1994 Adaptation of hepatitis C virus for persistent infection in patients with acute hepatitis. Gastroenterology 106:1344-1348 